\title{
LICITAÇÕES PÚBLICAS SUSTENTÁVEIS
}

Gil César Costa de Paula

Coordenador. Mestrado em direito, relações internacionais e desenvolvimento, PUC Goiás.

\section{Resumo}

Neste artigo procura-se discutir a questáo da sustentabilidade nas contrataçôes públicas, tendo em vista que o poder público no Brasil se constitui como um grande agente promotor do desenvolvimento econômico e necessita adequar sua aquisiçóes a agenda mundial da sustentabilidade.

\section{Palavras-chave}

Licitaçôes; Sustentabilidade; Poder público; Brasil.

\section{Abstract}

In this article we will discuss the issue of sustainability in public procurement, given that the government in Brazil is constituted as a great promoter of economic development and needs to adapt its acquisitions worldwide sustainability agenda.

\section{Key words}

Bids; Sustainability; Public Power; Brazil.

\section{Introdução}

A sustentabilidade nas contrataçóes públicas tem assumido status de discussão e deliberação dos órgãos de direção superior do poder judiciário, como o Conselho Nacional de Justiça - CNJ e Conselho Superior da Justiça do Trabalho-CSJT, sendo que este último editou a Resolução no 103 , de 25 de maio de 2012, na qual se esta preocupaçáo está assim expressa:

Trabalho revela-se em sintonia com um processo em curso no Brasil e no mundo, que consiste na percepçáo de que a forma como a humanidade vive e como tem se desenvolvido até agora não se sustentará por muito tempo, ante a constatação de que os recursos naturais presentes no planeta 
são em sua grande maioria finitos. Em todo o mundo buscam-se formas mais justas e sustentáveis de existir, ou seja, padrôes sustentáveis de produção e consumo, preservação dos recursos e redução das desigualdades sociais.

Boa parte da comunidade científica mundial entende que "não há como viabilizar sete bilhöes de pessoas, com o padrão de consumo e as aspiraçóes do mundo contemporâneo nos limites físicos da terra"

A consciência da responsabilidade de cada cidadão, das organizaçóes em geral e, em especial, do poder público, quanto a mudanças que viabilizem a continuidade da vida no planeta, vem crescendo a cada dia, ainda que com percalços, de forma contraditória, com avanços e retrocessos, e com as dificuldades inerentes aos processos humanos. Diversos exemplos e iniciativas condizentes com a necessária transformação que nos é exigida podem ser identificados em todo o mundo: avanços na ciência e na tecnologia, na participação social, nos arcabouços normativos nacionais e internacionais, na responsabilidade social por parte das organizaçóes, preocupaçáo crescente com o respeito aos direitos humanos e diversos outras iniciativas em todos os países.

O Plano de Ação para Produção e Consumo Sustentáveis - PPCS2 -, lançado em novembro de 2011 pelo Ministério do Meio Ambiente, é o documento guia das açóes de governo, do setor produtivo e da sociedade que direciona o Brasil para padróes mais sustentáveis de produção e consumo, com redução da pobreza.

Em seu primeiro ciclo, de 2011 a 2014, o PPCS focará seus esforços em seis áreas principais, a saber: educação para o consumo sustentável; varejo e consumo sustentável; aumento da reciclagem; compras públicas sustentáveis; construçôes sustentáveis; e Agenda Ambiental na Administração Pública - A3P, na qual figura como um dos eixos temáticos a Licitação Sustentável. Vale ressaltar que os outros eixos temáticos da A3P - uso racional dos recursos naturais e bens públicos; gestão adequada dos resíduos gerados; qualidade de vida no ambiente de trabalho e sensibilização e capacitação -, bem como as áreas de foco do PPCS, têm relação direta com as contrataçôes públicas.

O governo brasileiro trabalha no sentido de que o debate na Conferência das Nações Unidas para o Desenvolvimento Sustentável - Rio +20 - gire em torno de um compromisso global pela sustentabilidade, pela inclusão e pela erradicação da pobreza extrema no mundo. Tais propostas integram o documento com os oito objetivos que o governo brasileiro definiu para compor a pauta do encontro.

Nesse sentido, o documento oficial com a posiçáo do Brasil encaminhado à $\mathrm{ONU}$ enfatiza o papel do Estado como indutor e regulador do desenvolvimento sustentável: 
(...) é fundamental que o Estado retome seu papel de indutor e regulador do desenvolvimento, favorecendo a adoção de práticas econômicas e processos produtivos inovadores, calcados no uso racional e na proteção dos recursos naturais e na incorporação de pessoas excluidas à economia, por meio do acesso ao emprego, ao trabalho decente e à renda. Por meio de instrumentos econômicos e políticas públicas, o Estado deve remover barreiras e criar incentivos positivos, que facilitem a adesão do setor produtivo a padróes mais sustentáveis sob as óticas econômica, ambiental e social (...). O Estado pode ainda influenciar significativamente a adoção de modelos mais sustentáveis pela forma como aufere e aplica a receita. Os instrumentos de politica fiscal, associados à valoração de serviços ambientais, desempenham, nesse sentido, papel central no repertório de políticas do Estado, por meio dos quais podem ser estabelecidos estímulos positivos para a adoção de padróes mais sustentáveis em toda a cadeia produtiva (...). As compras públicas e investimentos também podem desempenhar papel nesse contexto.

O conceito de contrataçóes públicas sustentáveis foi objeto de reflexão do referido conselho que a propósito assim se posicionou:

\section{CONTRATAÇÓES PÚBLICAS SUSTENTÁVEIS}

As contrataçôes públicas sustentáveis constituem instrumentos relevantes de contribuição para a reorganização da economia com novos paradigmas. No Brasil inserem-se em um contexto de agendas nacionais que orientam as açóes e as políticas para o desenvolvimento sustentável, ou seja, para uma forma de desenvolvimento que satisfaça "as necessidades atuais sem comprometer a habilidade das futuras geraçóes de atender suas próprias necessidades".

Sob tal perspectiva, as contratações públicas sustentáveis representam a adequação da contratação ao que se chama consumo sustentável. Significa pensar a "proposta mais vantajosa para a administração" levando-se em conta náo apenas o menor preço, mas o custo como um todo, considerando a manutenção da vida no planeta e o bem-estar social. Vale lembrar que os recursos naturais do país e sua biodiversidade são recursos públicos e como tal devem ser preservados.

De acordo com o Guia de Compras Públicas Sustentáveis da Fundação Getúlio Vargas, "Licitação Sustentável é uma solução para integrar consideraçóes ambientais e sociais em todos os estágios do processo de compra e contrataçâo dos agentes públicos (governos) com objetivo de reduzir impactos à saúde humana, ao meio ambiente e aos direitos humano".

As compras governamentais, que no Brasil movimentam em torno de 10 a 15\% do PIB6, afetam setores importantes da economia e têm um grande poder de influenciar os rumos do mercado. Cabe ao governo, como grande comprador, além de dar o exemplo, estimular uma economia "que resulte em melhoria do bem-estar humano e equidade social, ao mesmo 
tempo em que gere valor para a Natureza, reduzindo significativamente os impactos e riscos sociais e ambientais e a demanda sobre recursos escassos do ecossistema e da sociedade".

Referida resoluçáo prevê dentre outros aspectos o seguinte:

\section{Sobre os critérios estabelece em seu artigo $1^{\circ}$ que:}

Art. 1o É aprovado o Guia Prático para inclusão de critérios de sustentabilidade a serem observados na aquisição de bens e na contratação de obras e serviços no âmbito da Justiça do Trabalho de primeiro e segundo graus, nos termos do anexo desta Resolução.

Determina o uso do guia por todos os órgáos da JT, do seguinte modo:

Art. 2o O Guia Prático será disponibilizado nos portais eletrônicos do Conselho Superior da Justiça do Trabalho e dos Tribunais Regionais do Trabalho, constituindo-se em instrumento de consulta para elaboração de editais de licitação, de termos de referência ou de especificações.

$\$ 1^{\circ}$ Os Tribunais Regionais do Trabalho poderão estabelecer outras práticas sustentáveis, além daquelas previstas no Guia Prático, consideradas as peculiaridade regionais.

Art. $7^{\circ}$ Os Tribunais Regionais do Trabalho incluirão em seus programas de capacitação cursos destinados a sensibilizar e instruir gestores e demais envolvidos para a concretização de compras e contrataçôes sustentáveis.

Art. $8^{\circ}$ Os Planejamentos Estratégicos da Justiça do Trabalho e dos Tribunais Regionais do Trabalho deverão conter indicadores e metas sobre compras e contrataçóes sustentáveis, a fim de mensurar, pelo menos, a disseminação do tema entre servidores e magistrados, a efetiva adoção de critérios de sustentabilidade nas compras e contrataçóes e a redução do consumo de insumos, a exemplo de água e energia elétrica.

\section{OBJETIVO:}

Cuida-se, enfim, de um guia em permanente construção. Solo fértil para que os servidores envolvidos com contrataçôes públicas contribuam com conhecimentos e experiências para as futuras revisôes e atualizaçôes. As diretrizes são norteadoras para o fazer com responsabilidade social. A intenção é que este guia estimule o surgimento de novas proposiçôes e pesquisas, que potencialize as ideias, gere açóes e propicie o surgimento de uma cultura para a sustentabilidade no âmbito da Justiça do Trabalho.

\section{Alguns destaques sobre as contrataçóes:}

\section{I - BENS DE CONSUMO E MATERIAIS PERMANENTES}

Recomendações gerais:

A opção por produtos mais sustentáveis deve ser feita de forma gradativa, com a definição de metas crescentes de aquisição, observando-se os preços e a oferta no mercado, com razoabilidade e proporcionalidade. 
Devem ser realizadas consultas ao Catálogo de Materiais (CATMAT) do Sistema de Compras do Governo Federal quanto aos itens classificados como mais sustentáveis, disponível no Portal www.comprasnet.gov.br;

Sempre que possível e no que couber, deve ser estabelecida margem de preferência para produtos manufaturados e serviços nacionais que atendam a normas técnicas brasileiras, em observância a Lei no 12.349/2010;

Deve ser observado, quando das contrataçóes de bens, serviços e obras, o atendimento às normas técnicas, elaboradas pela Associação Brasileira de Normas Técnicas (ABNT), nos termos da Lei no 4.150/62, bem como outras similares tudo com o objetivo de aferir e garantir a aplicação dos requisitos mínimos de qualidade, utilidade, resistência e segurança dos materiais utilizados.

\section{Comprovação quanto aos critérios exigidos:}

Em geral, a comprovação pode ser feita mediante inscrição nos rótulos, nas embalagens, por informaçóes disponíveis no site do fabricante e em sites dos órgáos competentes, por apresentação de certificaçáo emitida por instituição pública oficial, ou por instituição credenciada, ou por qualquer outro meio de prova que ateste que o bem fornecido cumpre com as exigências do edital;

Para produtos fabricados com madeira, deve-se exigir o certificado de procedência da madeira - DOF (emitido pelo IBAMA), comprovando a utilização de madeira legal e proveniente de manejo florestal responsável ou reflorestamento;

Para comprovação dos componentes da fórmula química dos produtos, observar a rotulagem, que é obrigatória e testada pela ANVISA.

\section{1- MATERIAL DE EXPEDIENTE}

Papel confeccionado com madeira de origem legal, com a apresentação do DOF12, preferencialmente reciclado. O fabricante ou o fornecedor deverá apresentar declaração que ateste o cumprimento da exigência quanto à origem legal da madeira; a declaração será dispensada quando o papel possuir o certificado CERFLOR13 ou FSC14;

Itens derivados do papel (envelopes, pastas classificadoras, agendas, cartôes de visita etc.) preferencialmente reciclados;

Envelopes reutilizáveis, preferencialmente de papel reciclado;

Itens constituídos em todo ou em parte por materiais reciclados atóxicos e biodegradáveis;

Lápis fabricados com madeira de origem legal, ou feito com material reciclado.

\section{2 - MATERIAL DE LIMPEZA}

Materiais menos agressivos ao meio ambiente; 
Produtos concentrados, que utilizam menor quantidade de matéria prima e água na sua fabricação e acondicionados em embalagens menores;

Sabão em barra e detergentes em pó preferencialmente à base de coco ou isentos de fósforo e, quando inexistentes no mercado, exigência de comprovação de teor que respeite o limite máximo de concentração de fósforo, conforme Resolução 359/2005 do CONAMA;

Produtos com embalagens recicladas ou recicláveis, de papeláo ou de plástico à base de etanol de cana-de-açúcar;

Os produtos deverão ser fabricados com tensoativos biodegradáveis15, e, preferencialmente, com matérias primas de origem vegetal e não poluente, $100 \%$ biodegradáveis.

Esponjas fabricadas com solvente à base d'água;

Produtos que possuam comercialização em refil16;

Os produtos deverão ser notificados ou registrados na ANVISA, conforme determina a legislação (www.anvisa.gov.br/saneantes/legis/index. htm).

\section{3 - CARTUCHOS E TONER}

Nas aquisiçôes de cartuchos de tinta e de toner, o fornecedor deve indicar como será feita a coleta para a correta destinação final pelo fabricante;

Quando regulamentados os acordos setoriais previstos na Lei $\mathrm{n}^{\circ}$ $12.305 / 2010$, deverá ser exigida a logística reversa, cabendo ao fornecedor o recolhimento do material;

A sistemática de recolhimento deverá indicar as quantidades mínimas de cartuchos a serem recolhidos por evento, os responsáveis pelo recolhimento, bem como a especificação e detalhamento da destinação dos cartuchos usados;

Somente serão considerados apropriados os procedimentos de destinação dos cartuchos usados quando orientados para os seguintes objetivos:

o Reaproveitamento ou reutilizaçáo das peças e componentes dos cartuchos não sujeitos a desgastes, efetivados sob supervisão do fabricante do cartucho;

Destinação ambientalmente adequada dos resíduos dos cartuchos, devidamente licenciada pelo órgão ambiental competente, a ser efetivada pelo fabricante do cartucho ou por representante autorizado.

\section{4 - PILHAS E BATERIAS}

\section{$\mathrm{Na}$ aquisiçáo de pilhas e baterias, deve-se exigir que:}

As embalagens das pilhas e baterias, fabricadas no País ou importadas, contenham as informações que atendam ao art. 14 da Resolução no 401/2008 - CONAMA; 
No corpo das pilhas e baterias conste informaçóes que atendam ao disposto no art. 16 da Resoluçáo no 401/2008 - CONAMA;

Nas especificações de baterias chumbo-ácido, e pilhas e baterias níquelcádmio e óxido de mercúrio, sejam observados os limites máximos desses elementos, conforme o disposto na

Resolução no 401/2008 - CONAMA;

O A comprovação dar-se-á pela apresentação de laudo do laboratório acreditado pelo Inmetro, comprovando os teores máximos permitidos de chumbo, cádmio e mercúrio, previstos na Resolução CONAMA n ${ }^{\circ}$ $401 / 2008$, para cada tipo de produto listado naquele documento;

Devem ser adquiridas pilhas e baterias de fabricantes ou importadores que estejam inscritos no Cadastro Técnico Federal de Atividades Potencialmente Poluidoras ou Utilizadoras de Recursos Ambientais - CTF.

Nas aquisiçóes de pilhas e baterias, o fornecedor deve indicar como será feita a coleta para a correta destinação final pelo fabricante;

Quando regulamentados os acordos setoriais previstos na Lei $\mathrm{n}^{\circ}$ $12.305 / 2010$, deverá ser exigida a logística reversa, cabendo ao fornecedor o recolhimento do material;

Deve ser verificada a legislaçáo local para recolhimento de pilhas e baterias; $\mathrm{O}$ armazenamento de pilhas e baterias deve atender aos critérios ambientais.

\section{5 - EQUIPAMENTOS DE TECNOLOGIA DA INFORMAÇÁO E COMUNICAÇÃO}

Os Tribunais deveráo exigir no edital que os equipamentos de tecnologia de informação e comunicação, bem como os seus periféricos e acessórios não contenham substâncias perigosas como mercúrio $(\mathrm{Hg})$, chumbo $(\mathrm{Pb})$, cromo hexavalente $(\mathrm{Cr}(\mathrm{VI}))$, cádmio $(\mathrm{Cd})$, bifenil- polibromados (PBBs), éteres difenil-polibromados (PBDEs) em concentração acima da recomendada pela diretiva da Comunidade Econômica Européia Restriction of Certain Hazardous Substances - RoHS17;

As especificaçóes devem contemplar, preferencialmente, as configuraçôes aderentes aos computadores sustentáveis, também chamados TI Verde, conforme dispóe a Portaria $n^{\circ} 2 / 2010$, da Secretaria de Logística e Tecnologia da Informação do Ministério do Planejamento Orçamento e Gestão, e atualizaçóes posteriores, disponíveis na rede mundial de computadores no endereço http://www.governoeletronico.gov.br/ sispconteudo /especificacoes-tic, utilizando assim materiais que reduzam o impacto ambiental.

As aquisiçôes de bens de tecnologia da informação devem estar em consonância com o Plano Diretor de Tecnologia da Informaçáo (PDTI) da Justiça do Trabalho, e de cada Tribunal em particular; 
O edital deve exigir do fornecedor (fabricante, importador, distribuidor ou comerciante) a indicação das medidas necessárias para assegurar a operacionalização do recolhimento dos equipamentos que contenham materiais perigosos, inclusive em relaçáo ao suprimento (cartuchos, toners);

Nas aquisiçôes de impressoras deverá ser exigida da contratada a apresentação de Plano de Gerenciamento de Resíduos Sólidos, comprovando a correta destinação de resíduos perigosos, inclusive para o recolhimento dos cartuchos de tinta e de toner usados.

\section{II - CONTRATOS DE SERVIÇOS}

Sem prejuízo da legislação e das normas vigentes que amparam as contratações de serviços pela Administração Pública, na elaboração do Projeto Básico ou Termo de Referência para as contrataçóes da Justiça do Trabalho deverá constar que:

Para os serviços que envolvam a utilizaçáo de máo de obra, em geral:

A contratada deverá obedecer às normas técnicas, de saúde, de higiene e de segurança do trabalho, de acordo com as normas do Ministério do Trabalho e Emprego;

Para os serviços de impressáo e de cópia:

A contratada devera proceder à separação dos resíduos recicláveis descartados de forma seletiva, especialmente o papel, de acordo com o programa de coleta seletiva do órgão, em observância ao Decreto n 5.940/2006;

Deverá ser exigida da contratada a apresentação de sistemática para o recolhimento dos cartuchos de tinta e de toner usados, e de sua correta destinação, na forma indicada no item 5.3 deste Guia.

O uso das citaçóes acima, embora deixem o texto carregado para o leitor, é importante para elucidar o tratamento dado pelos conselhos superiores da justiça brasileira sobre o tema.

O conceito de contrataçóes públicas sustentáveis será objeto de reflexão a seguir, na qual procuraremos fazer apenas as citaçóes que forem necessárias a compreensão do assunto.

\section{Sustentabilidade e Governança Licitações Sustentáveis}

\subsection{Aspectos Conceituais}

A que se deixar claro que não existe, em termos legais, a definição de Licitação Sustentável. O que existe são definiçóes doutrinárias, nesse trabalho apresentamos algumas delas.

Para Ana Maria Vieira Neto (2014, p.17), compras públicas sustentáveis são a “política pública de contrataçóes que usa o poder de compra do Estado para implementar o 
desenvolvimento econômico e social, bem como a redução do impacto ambiental, usando critérios e procedimentos diferenciados."

Rejane Maria Tavares Santos (2011, p. 57), em sua dissertação de Mestrado, define como:

As compras públicas sustentáveis correspondem a uma forma de inserção de critérios ambientais nas compras e contrataçóes realizadas pela Administração Pública, visando à maximização do valor adicionado (utilidade, qualidade, durabilidade) e, ao mesmo tempo, a minimização dos impactos ambientais e sociais adversos.

Para Rachel Biderman (et all, 2008, p. 21):

A licitação sustentável é uma solução para integrar considerações ambientais e sociais em todos os estágios do processo da compra e contratação dos agentes públicos (de governo) com o objetivo de reduzir impactos à saúde humana, ao meio ambiente e aos direitos humanos. A licitação sustentável permite o atendimento das necessidades específicas dos consumidores finais por meio da compra do produto que oferece o maior número de benefícios para o ambiente e a sociedade.

Nesse sentido, as contratações sustentáveis abrangem as três dimensões do desenvolvimento sustentável, definidos pelo Relatório Brundtland e Agenda 21, que são sociedade, meio ambiente e tecnologia.

Estas devem considerar os impactos econômicos, sociais e ambientais durante todo o ciclo de vida da compra, desde o desenho do produto, passando pela fabricação ou cadeia de fornecedores, o uso e a gestão e tratamento final que este produto sofrerá.

\subsection{Aspectos Legais}

Antes da promulgaçáo da Constituição Federal de 1988, já se via, por parte do legislador brasileiro, a preocupação com a preservação do meio ambiente, o que deu origem a uma ampla legislação a respeito do tema, dividida em leis, decretos e instruçóes normativas, entre outros.

A Política Nacional do Meio Ambiente foi promulgada em 1981, como Lei n. 6.938, estabelecendo os princípios da regulamentação ambiental, definindo os principais conceitos de direito ambiental e "visando assegurar, no País, condiçóes ao desenvolvimento socioeconômico, aos interesses da segurança nacional e à proteção da dignidade da vida humana”.

Em 1985, foi promulgada a Lei 7.347 - Lei da Ação Civil Pública, que tutela os direitos difusos e coletivos e regulamentou as açóes de responsabilidade por dano causado ao meio ambiente e ao consumidor, entre outros direitos. 
Como informado no Capítulo I deste trabalho, a Constituição Federal reservou o Capítulo VI ao tema Meio Ambiente, tratando-o mais especificamente no artigo 225, que diz:

Art. 225. Todos têm direito ao meio ambiente ecologicamente equilibrado, bem de uso comum do povo e essencial à sadia qualidade de vida, impondo-se ao Poder Público e à coletividade o dever de defendê-lo e preservá-lo para as presentes e futuras geraçóes.

(grifamos)

O legislador, porém, não limitou o assunto a este artigo, uma vez que, cita-o diversas vezes no escopo da Carta Magna, estabelecendo competências e responsabilidades para sua manutenção e preservação.

No Título VII, que trata da ordem econômica e financeira, a CF/88 estabeleceu entre seus princípios a proteção ao meio ambiente, a redução das desigualdades regionais e sociais e o tratamento favorecido para as empresas de pequeno porte, princípios que também estão incluídos na definição de Desenvolvimento Sustentável, do Relatório Brundtland:

Art. 170. A ordem econômica, fundada na valorização do trabalho humano e na livre iniciativa, tem por fim assegurar a todos existência digna, conforme os ditames da justiça social, observados os seguintes princípios:

(...)

VI - defesa do meio ambiente, inclusive mediante tratamento diferenciado conforme o impacto ambiental dos produtos e serviços e de seus processos de elaboração e prestação;

VII - reduçáo das desigualdades regionais e sociais;

VIII - busca do pleno emprego;

IX - tratamento favorecido para as empresas de pequeno porte constituídas sob as leis brasileiras e que tenham sua sede e administraçáo no País.

Art. 179. A União, os Estados, o Distrito Federal e os Municípios dispensaráo às microempresas e às empresas de pequeno porte, assim definidas em lei, tratamento jurídico diferenciado, visando a incentivá -las pela simplificaçáo de suas obrigaçóes administrativas, tributárias, previdenciárias e creditícias, ou pela eliminação ou redução destas por meio de lei.

(grifamos)

Como pontapé inicial para as chamadas Compras Públicas Sustentáveis, em 2006, foi editada a Lei Complementar n. 123, estabelecendo normas gerais relativas 
ao tratamento diferenciado e favorecido a ser dispensado às microempresas e empresas de pequeno porte, uma vez que, como visto, o conceito de sustentabilidade engloba também o desenvolvimento econômico.

Nas palavras do Relatório Brundtland (1991, p.3-4), “os governos e as entidades multilaterais tornam-se cada vez mais conscientes da impossibilidade de separar as questôes relativas ao desenvolvimento econômico das questôes relativas ao meio ambiente."

Em resposta à aceitação do Brasil aos termos das várias convenções sobre meio ambiente da ONU, em especial aos termos do Protocolo de Montreal, Agenda 21 Global e Protocolo de Kyoto, foram surgindo várias normatizaçóes esparsas, que incluíram critérios de sustentabilidade nas compras públicas, como exemplos:

a) Decreto n. 2.783/98, proibiu entidades do governo federal de comprar produtos ou equipamentos contendo substâncias degradadoras da camada de ozônio;

b) Decreto n. 4.131/02, dispôs sobre medidas emergenciais de redução do consumo de energia elétrica no âmbito da Administração Pública Federal;

c) Resolução CONAMA n. 307/02, estabeleceu critérios e procedimentos para gestão de resíduos na construção civil;

d) Portaria n. 61/08 do Ministério do Meio Ambiente, estabeleceu práticas de sustentabilidade ambiental quando das compras públicas sustentáveis do órgão:

Art. $1^{\circ}$ Nas licitaçóes e demais formas de contrataçóes promovidas pelo Ministério do Meio Ambiente e suas entidades vinculadas deverão ser observadas:

I - a preferência por fornecedores e produtos comprovadamente de menor impacto ambiental;

II - justificativa e especificaçóes técnicas ambientais, de forma a atender ao interesse da Administração Pública, de preservaçáo do meio ambiente e do bem estar social.

(grifamos)

e) Portaria n. 43/09 do Ministério do Meio Ambiente, proibiu o uso do amianto em obras públicas e veículos de todos os órgãos vinculados à administração pública;

f) Lei n. 12.187/09, instituiu a Política Nacional sobre Mudança do Clima PNMC, estabelecendo preferência para a exploração de serviços públicos e recursos naturais, para as propostas que propiciem maior economia de energia, água e outros recursos naturais e redução da emissão de gases visando: 
Art. $4^{\circ}$ - A Política Nacional sobre Mudança do Clima - PNMC visará:

I - à compatibilizaçáo do desenvolvimento econômico-social com a proteção do sistema climático;

II - à redução das emissóes antrópicas de gases de efeito estufa em relação às suas diferentes fontes;

III- (VETADO);

IV - ao fortalecimento das remoçóes antrópicas por sumidouros de gases de efeito estufa no território nacional;

$\mathrm{V}$ - à implementação de medidas para promover a adaptação à mudança do clima pelas 3 (três) esferas da Federação, com a participação e a colaboração dos agentes econômicos e sociais interessados ou beneficiários, em particular aqueles especialmente vulneráveis aos seus efeitos adversos; VI - à preservação, à conservação e à recuperação dos recursos ambientais, com particular atenção aos grandes biomas naturais tidos como Patrimônio Nacional;

VII - à consolidação e à expansão das áreas legalmente protegidas e ao incentivo aos reflorestamentos e à recomposição da cobertura vegetal em áreas degradadas;

VIII - ao estímulo ao desenvolvimento do Mercado Brasileiro de Redução de Emissões - MBRE.

Parágrafo Único . Os objetivos da Política Nacional sobre Mudança do Clima deveráo estar em consonância com o desenvolvimento sustentável a fim de buscar o crescimento econômico, a erradicaçáo da pobreza e a reduçáo das desigualdades sociais.

(grifamos)

Em 2010, a Lei 8.666/93 foi alterada pela Lei 12.349, incluindo em seu artigo $3^{\circ}$, como objetivo da licitação "a promoção do desenvolvimento nacional sustentável", que não existia na lei original:

Art. $3^{\circ}$ A licitação destina-se a garantir a observância do princípio constitucional da isonomia, a seleção da proposta mais vantajosa para a administração e a promoçáo do desenvolvimento nacional sustentável e será processada e julgada em estrita conformidade com os princípios básicos da legalidade, da impessoalidade, da moralidade, da igualdade, da publicidade, da probidade administrativa, da vinculaçáo ao instrumento convocatório, do julgamento objetivo e dos que lhes são correlatos. (grifamos)

Em consequência desta alteração, foram sendo editadas normatizações, visando dar efetividade à nova determinação da Lei Geral de Licitaçôes, como exemplo, citamos: 
a) Instrução Normativa n. 01/10 do Ministério do Planejamento Orçamento e Gestão, dispôs sobre critérios de sustentabilidade ambiental na aquisição de bens, contratação de serviços ou obras pela administração pública direta, autárquica e fundacional:

Art. $1^{\circ}$ Nos termos do art. $3^{\circ}$ da Lei n. 8.666, de 21 de junho de 1993, as especificaçóes para a aquisiçáo de bens, contratação de serviços e obras por parte dos órgáos e entidades da administração pública federal direta, autárquica e fundacional deveráo conter critérios de sustentabilidade ambiental, considerando os processos de extraçáo ou fabricaçáo, utilizaçáo e descarte dos produtos e matérias primas.

(grifamos)

b) Lei n. 12.305/10, instituiu a Política Nacional de Resíduos Sólidos, estabelecendo prioridade nas aquisiçóes e contrataçóes governamentais de produtos reciclados e recicláveis, entre outros:

Art. 6o São princípios da Política Nacional de Resíduos Sólidos:

(...)

IV - o desenvolvimento sustentável;

$\mathrm{V}$ - a ecoeficiência, mediante a compatibilização entre o fornecimento, a preços competitivos, de bens e serviços qualificados que satisfaçam as necessidades humanas e tragam qualidade de vida e a reduçáo do impacto ambiental e do consumo de recursos naturais a um nível, no mínimo, equivalente à capacidade de sustentaçáo estimada do planeta;

(...)

VIII - o reconhecimento do resíduo sólido reutilizável e reciclável como um bem econômico e de valor social, gerador de trabalho e renda e promotor de cidadania;

(...)

IX - o respeito às diversidades locais e regionais;

(...)

Art. 7o Sáo objetivos da Política Nacional de Resíduos Sólidos:

I - proteção da saúde pública e da qualidade ambiental;

II - não geração, redução, reutilização, reciclagem e tratamento dos resíduos sólidos, bem como disposição final ambientalmente adequada dos rejeitos;

III - estímulo à adoçáo de padróes sustentáveis de produçáo e consumo de bens e serviços;

IV - adoçáo, desenvolvimento e aprimoramento de tecnologias limpas como forma de minimizar impactos ambientais; 
(...)

XI - prioridade, nas aquisiçóes e contrataçóes governamentais, para:

a) produtos reciclados e recicláveis;

b) bens, serviços e obras que considerem critérios compatíveis com padrôes de consumo social e ambientalmente sustentáveis;

XII - integração dos catadores de materiais reutilizáveis e recicláveis nas açóes que envolvam a responsabilidade compartilhada pelo ciclo de vida dos produtos;

(...)

XV - estímulo à rotulagem ambiental e ao consumo sustentável.

(grifamos)

c) Lei 12.462/2011, instituiu o Regime Diferenciado de Contrataçôes Públicas - RDC para os eventos: Jogos Olímpicos e Paralímpicos de 2016, a Copa das Confederaçóes da Federação Internacional de Futebol Associação - Fifa 2013 e a Copa do Mundo de futebol de 2014, entre outros:

Art. 20 $\mathrm{Na}$ aplicação do RDC, deverão ser observadas as seguintes definiçôes:

(...)

IV - projeto básico: conjunto de elementos necessários e suficientes, com nível de precisão adequado, para, observado o disposto no parágrafo único deste artigo:

(...)

b) assegurar a viabilidade técnica e o adequado tratamento do impacto ambiental do empreendimento.

(...)

Art. $4^{\circ}$ Nas licitaçóes e contratos de que trata esta Lei seráo observadas as seguintes diretrizes:

(...)

III - busca da maior vantagem para a administraçáo pública, considerando custos e benefícios, diretos e indiretos, de natureza econômica, social ou ambiental, inclusive os relativos à manutenção, ao desfazimento de bens e resíduos, ao índice de depreciação econômica e a outros fatores de igual relevância;

(...)

$\$ 1^{\circ}$ As contrataçóes realizadas com base no RDC devem respeitar, especialmente, as normas relativas à:

I - disposiçáo final ambientalmente adequada dos resíduos sólidos gerados pelas obras contratadas; 
II - mitigação por condicionantes e compensaçáo ambiental, que serão definidas no procedimento de licenciamento ambiental;

III - utilizaçáo de produtos, equipamentos e serviços que, comprovadamente, reduzam o consumo de energia e recursos naturais; (grifamos)

d) Decreto n. 7.746/12, regulamentou o art. $3^{\circ}$ da Lei 8.666 estabelecendo critérios, práticas e diretrizes para a promoção do desenvolvimento nacional sustentável nas contrataçóes públicas:

Art. 2० A administração pública federal direta, autárquica e fundacional e as empresas estatais dependentes poderáo adquirir bens e contratar serviços e obras considerando critérios e práticas de sustentabilidade objetivamente definidos no instrumento convocatório, conforme o disposto neste Decreto.

Parágrafo Único. A adoçáo de critérios e práticas de sustentabilidade deverá ser justificada nos autos e preservar o caráter competitivo do certame.

Art. $3^{\circ}$ Os critérios e práticas de sustentabilidade de que trata o art. 2o serão veiculados como especificaçáo técnica do objeto ou como obrigaçáo da contratada.

(...)

Art. 4o São diretrizes de sustentabilidade, entre outras:

I - menor impacto sobre recursos naturais como flora, fauna, ar, solo e água;

II - preferência para materiais, tecnologias e matérias-primas de origem local;

III - maior eficiência na utilizaçáo de recursos naturais como água e energia;

IV - maior geraçáo de empregos, preferencialmente com máo de obra local;

$\mathrm{V}$ - maior vida útil e menor custo de manutenção do bem e da obra;

VI - uso de inovaçóes que reduzam a pressão sobre recursos naturais; e

VII - origem ambientalmente regular dos recursos naturais utilizados nos bens, serviços e obras.

Art. $5^{\circ} \mathrm{A}$ administraçáo pública federal direta, autárquica e fundacional e as empresas estatais dependentes poderáo exigir no instrumento convocatório para a aquisição de bens que estes sejam constituídos por material reciclado, atóxico ou biodegradável, entre outros critérios de sustentabilidade. 
Art. $6^{\circ}$ As especificaçóes e demais exigências do projeto básico ou executivo para contratação de obras e serviços de engenharia devem ser elaboradas, nos termos do art. 12 da Lei n. 8.666, de 1993, de modo a proporcionar a economia da manutenção e operacionalização da edificação e a reduçáo do consumo de energia e água, por meio de tecnologias, práticas e materiais que reduzam o impacto ambiental.

Art. $7^{\circ} \mathrm{O}$ instrumento convocatório poderá prever que o contratado adote práticas de sustentabilidade na execuçáo dos serviços contratados e critérios de sustentabilidade no fornecimento dos bens.

(...)

(grifamos)

e) Lei Complementar n. 147/14, alterou a LC n. 123/06 - Estatuto Nacional da Microempresa e da Empresa de Pequeno Porte. Contém disposiçóes de natureza tributária, com o objetivo de fomentar a atividade empresarial por meio da redução da carga fiscal e da simplificação das formalidades nessa área, e inclui disposições relativas à preferência de participação da ME e EPP nos certames licitatórios:

Art. 42. Nas licitaçóes públicas, a comprovação de regularidade fiscal das microempresas e empresas de pequeno porte somente será exigida para efeito de assinatura do contrato.

(...)

Art. 44. Nas licitaçôes será assegurada, como critério de desempate, preferência de contrataçáo para as microempresas e empresas de pequeno porte.

$\$ 1$ lo Entende-se por empate aquelas situaçóes em que as propostas apresentadas pelas microempresas e empresas de pequeno porte sejam iguais ou até $10 \%$ (dez por cento) superiores à proposta mais bem classificada.

$\$ 2$ o Na modalidade de pregáo, o intervalo percentual estabelecido no $\$ 1$ o deste artigo será de até $5 \%$ (cinco por cento) superior ao melhor preço.

Art. 45. Para efeito do disposto no art. 44 desta Lei Complementar, ocorrendo o empate, proceder-se-á da seguinte forma:

I - a microempresa ou empresa de pequeno porte mais bem classificada poderá apresentar proposta de preço inferior àquela considerada vencedora do certame, situação em que será adjudicado em seu favor o (...)

Art. 47. Nas contrataçóes públicas da administraçáo direta e indireta, autárquica e fundacional, federal, estadual e municipal, deverá 
ser concedido tratamento diferenciado e simplificado para as microempresas e empresas de pequeno porte objetivando a promoçáo do desenvolvimento econômico e social no âmbito municipal e regional, a ampliaçáo da eficiência das políticas públicas e o incentivo à inovaçáo tecnológica.

(...)

Art. 48. Para o cumprimento do disposto no art. 47 desta Lei Complementar, a administraçáo pública:

I - deverá realizar processo licitatório destinado exclusivamente à participaçáo de microempresas e empresas de pequeno porte nos itens de contratação cujo valor seja de até $\mathrm{R} \$$ 80.000,00 (oitenta mil reais);

II - poderá, em relação aos processos licitatórios destinados à aquisição de obras e serviços, exigir dos licitantes a subcontrataçáo de microempresa ou empresa de pequeno porte;

III - deverá estabelecer, em certames para aquisição de bens de natureza divisível, cota de até $\mathbf{2 5 \%}$ (vinte e cinco por cento) do objeto para a contrataçáo de microempresas e empresas de pequeno porte.

$\$ 3$ o Os benefícios referidos no caput deste artigo poderão, justificadamente, estabelecer a prioridade de contrataçáo para as microempresas e empresas de pequeno porte sediadas local ou regionalmente, até o limite de $10 \%$ (dez por cento) do melhor preço válido.

(grifamos)

Encontramos vários julgados do Tribunal de Contas da União acatando a necessidade de se instituir, no âmbito da Administração Pública, critérios de sustentabilidade nas contrataçóes.

Vejamos alguns exemplos:

Acórdáo 1978/2009, TCU:

8.1.1 o conceito da proposta mais vantajosa, inserido no caput do artigo $3^{\circ}$ da Lei n. 8.666/1993, náo se confunde com o de 'mais barato', visto que sua compreensão pressuporia o atendimento das exigências constitucionais de economicidade e eficiência; 'as circunstâncias de uma determinada situaçáo específica podem fazer com que o fornecimento por diversas empresas não seja útil para a Administração, sendolhe manifestamente mais vantajoso que o objeto do contrato seja adjudicado a um único fornecedor'; em seguida, ampara o entendimento nos ensinamento de Antônio Carlos Cintra do Amaral, textualmente: 'É comum considerar-se que a maior vantagem para a Administraçáo está sempre no menor preço. Isso reflete o entendimento, equivocado, de 
que a lei consagra a tese de que o mais barato é sempre o melhor, sem contemplaçáo com a técnica e a qualidade. Esse entendimento não corresponde ao disposto na Lei 8.666/93 e conflita com os princípios da razoabilidade, eficiência e economicidade, que regem os atos administrativos, inclusive os procedimentos licitatórios.'

Acórdáo 1752/2011, TCU:

ACORDAM os Ministros do Tribunal de Contas da União, reunidos em Sessão do Plenário, ante as razões expostas pelo Relator, em:

9.1. recomendar ao Ministério do Planejamento, Orçamento e Gestão que apresente, em 90 (noventa) dias, um plano de açáo visando a orientar e a incentivar todos os órgáos e entidades da Administraçáo Pública Federal a adotarem medidas para o aumento da sustentabilidade e eficiência no uso de recursos naturais, em especial energia elétrica, água e papel, considerando a adesáo do País aos acordos internacionais: Agenda 21, Convenção-Quadro das Naçóes Unidas sobre Mudança do Clima e Processo Marrakech, bem como o disposto na Lei n. 12.187, de 29 de dezembro de 2009, na Lei n. 9.433, de 8 de janeiro de 1997, na Lei n. 10.295, de 17 de outubro de 2001, no Decreto n. 5.940, de 25 de outubro de 2006, e na Instrução Normativa SLTI/MP n. 1 , de 19 de janeiro de 2010;

\section{Acórdáo N. 3241/2013 - TCU - 2a Câmara}

1.8.1. a náo adoçáo de critérios de sustentabilidade ambiental na realizaçáo de licitaçóes contraria o art. $3^{\circ}$ da Lei 8.666/1993 e a Instruçáo Normativa SLTI 01/2010;

Acórdáo N. 4482/2014 - TCU - 2a Câmara

Recomendaçáo ao Conselho Administrativo de Defesa Econômica (CADE) para que promova campanhas educativas e de conscientizaçáo acerca da sustentabilidade ambiental junto aos seus servidores e adote critérios de sustentabilidade ambiental em suas licitaçóes, na aquisição de bens, materiais de TI e na contratação de obras e serviços.

\section{Conclusões}

Diante de tudo isso, pode-se concluir que de 2006 para cá, ou em pouco mais de 9 anos, a legislação brasileira sobre aquisições sustentáveis amadureceu a ponto de trazer normas específicas, leis, decretos e, especialmente, portarias, instruçóes normativas e resoluçóes editadas por órgãos e entidades que integram o Sistema Nacional do Meio Ambiente, assim como julgados dos órgãos de controle que amparam amplamente o gestor público a nortear suas ações no sentido de implementar as compras públicas sustentáveis no âmbito das repartiçóes, visando fomentar o desenvolvimento econômico e social e a preservação do meio ambiente. 
Por outro lado, falta preparar tecnicamente a administração pública no Brasil para verificar a conformidade das licitaçôes públicas com a observância dos critérios de sustentabilidade definidos nos instrumentos normativos citados.

\section{Referências}

BRAILE, Pedro Márcio. Celulose e Papel. Manual de tratamento de Águas Residuárias Industriais. CETESB, SP, 1979.

BRÜSEKE, Franz Josef. O Problema do Desenvolvimento Sustentável. NAEA, Núcleo de Estudos Amazônicos, UFPA, Nov., 1993.

BRÜSEKE, Franz Josef. Para uma Teoria Náo-linear e Pluri-dimencional do Desenvolvimento. in : Vieira, Paulo Freire e Maimon, Dália. As Ciências Sociais e a Questão Ambiental: Rumo à Interdisciplinaridade, Ed. APED \& NAEA, 1993.

BOULDING, Kenneth E. What do We Want to Sustain? Environmentalism and Human Evaluations. Ecological Economics. The Science and Management of Sustainability, 1991.

C’ANEPA, Eugênio M. A Gestão dos Recursos Hídricos sob a perspectiva Ambiental. Rev. Ciência e Ambiente III, (4), jan./jun., 1992.

CARNEIRO, José Mário B., MAGYAR, Ana Lúcia e GRANJA, Sandra Inês B. Meio Ambiente, Empresário e Governo: Conflitos ou Parcerias.Revista de Administração de Empresas, SP, v.33, n.33, 1993.

CAVALCANTI, Clóvis. Em Busca da Compatibilização entre a Ciência da Economia e a Ecologia: Bases da Economia Ecológica. in : Vieira, Freire Paulo e Maimon, Dália. As Ciências Sociais e a Questão Ambiental: Rumo à Interdisciplinaridade, Ed. APED \& NAEA, 1993.

CHOUCRI, Nazli. Meio ambiente e as Multinacionais. Rev. Diálogo, V. 25, $\mathrm{n}^{\circ} 2$, 1992.

CONSTANZA, Rbert, DALY, Hermann E. e BARTHOLOMEW, Joy A. Goals, Agenda and Policy Recommendations for Ecological Economics. The Science and Management of Sustainability, 1991.

DONAIRE, Denis. Consideraçóes sobre a Influência da Variável Ambiental na Empresa. Revista de Administração de Empresas, SP, v. 34, n.2, mar./ abr., 1994.

DALCERO, Pedro. Meio Ambiente e Direitos Humanos numa Sociedade Global”. Rev. Proposta, n 53, Maio, 1992.

DALY, Herman E. Elements of Environmental Macoeconomcs. The Science and Management of Sustainability, 1991. 
DUFFY, Donald P. e PORTTER, Juliana E. Environmental Auditing. Rev. Environ Sci Technol, v.26, n.9, sept., 1992.

FURTADO, André. Opçóes Tecnológicas e Desenvolvimento do Terceiro Mundo. Workshop, A Economia da Sustentabilidade: Princípios, Desafios, Aplicaçôes. Fundação Joaquim Nabuco, 12-15 de set. de 1994.

GUILLAUD, Yann. O Pensamento do Pr. Ignacy Sachs: da Economia Política ao Ecodesenvolvimento. NAEA, Núcleo de Estudos Amazônicos, 1993.

GANA, Grupo de Apoio à Normalização Ambiental. ISO TC-207. O Brasil e a Futura Normalizaçáo Ambiental-ISO 14000. Rio de Janeiro, setembro, 1994.

GUEDES, Ana Lúcia Malheiros. O Papel da Empresa Multinacional no Contexto de Meio Ambiente e Relaçóes Internacionais._Rev. Contexto Internacional, RJ, vol. 15, n.2, jul./dez., 1993.

IBGE, Instituto Brasileiro de Geografia e Estatística. A Ocupaçáo do Território e o Meio Ambiente. Diagnóstico Brasil, 1990.

PAULA, Gil César Costa de. Metodologia da Pesquisa Científica, Goiânia, editora Vieira, 2010.

SILVA NETO, Amaro Moraes e. Privacidade na internet: um enfoque jurídico. São Paulo: Edipro, 2001.

TORRES, Rafael Lopes. Licitaçôes sustentáveis: sua importância e seu amparo constitucional e legal. Disponível em: http://portal2.tcu.gov.br/portal/pls/portal/ docs/2493665.PDF Acesso em 02/12/14 09h28min

TRIGUEIRO, André. Mundo sustentável - Abrindo espaço na mídia para um planeta em transformação. São Paulo: Globo, 2005.

VEIGA, José Eli da. A emergência socioambiental. São Paulo: Editora Senac São Paulo, 2007. 